\title{
Comparative Study of Released Javan Hawk-Eagle (Nisaetus bartelsi) And Changeable Hawk-Eagle (Nisaetus cirrhatus) Based On Satellite Tracker Data
}

\author{
Gunawan $^{1 *}$, Fajar Aji D.N², Tauhid Nursalim ${ }^{3}$, Danafia Permana ${ }^{4}$, and Susanti Withaningsih Pa,6, $^{5}$ \\ ${ }^{1}$ Yayasan Konservasi Elang Indonesia \\ ${ }^{2}$ Balai Besar Konservasi Sumber Daya Alam Jawa Timur, Indonesia \\ ${ }^{3}$ Fakultas Kedokteran Hewan Universitas Gajah Mada, Yogyakarta, Indonesia \\ ${ }^{4}$ PT.Pertamina Fuel Terminal Madiun, Jawa Timur, Indonesia \\ ${ }^{5}$ Departments Biology, Faculty of Mathematic \& Natural Science, Universitas Padjadjaran, Indonesia \\ ${ }^{6}$ Center for Environment and Sustainability Science, Universitas Padjadjaran, Indonesia \\ ${ }^{7}$ Environment Science and Sustainability Science Program, Postgraduate School, Universitas Padjadjaran, Indonesia
}

\begin{abstract}
The release of a rehabilitated raptor, defined as an effort to release the raptor back into nature, have been done in Indonesia; however, only about $2 \%$ were monitored for more than one year. This is because long time intensive monitoring using simple observation equipment is difficult to do because of limited resources. Thus, more modern equipment - oneof which is satellite radio used in this research needs to be used. The use of satellite radio to monitor the movement of rehabilitated raptors was carried out for the first time in 2018 for juvenile male Javan hawk-eagles (N.bartelsi) and adult female Changeable hawk-eagles (N.cirrhatus). The results of the monitoring of these two types of raptors showed that they mostly used forested areas close to water sources. Both types of eagles had the farthest flight distance with an average distance of $\pm 1,000 \mathrm{~m} /$ day occurring at week 4 . Thus, it can be concluded that the rehabilitation efforts for these eagles were successful and that they had adapted to their new habitats as wild raptors.
\end{abstract}

\section{Introduction}

The release of rehabilitated raptors has been carried out extensively in Indonesia, but according to [4] only about $2 \%$ are monitored for a period of more than 1 year. The difficulty in finding released raptors is the main reason why there has been no long-term monitoring. However, the data from this monitoring is essential to evaluate the rehabilitation and release programs that have done.

Johnston (2007) states that the use of radio technology to determine the movements of raptors has been carried out from three decades ago, and this technology is now used in various countries to determine the movement patterns of several types of migratory raptors [8]. However, the use of satellite radio for raptor in Indonesia is only minimally used.

The satellite radio in Indonesia was first used in the release of a rehabilitated juvenile male Javan hawkeagle (about 2 years old) released in the Cagar Alam (Nature Reserve) area of Mount Sigogor (East Java) and an adult female changeable hawk-eagle released in the Tahura Bunder area (Yogyakarta) in 2017.

The Javan hawk-eagle (Nisaetus batelsi) and the changeable hawk-eagle (Nisaetus cirrhatus) are two types of raptors from the same genus. The Javan hawkeagle is endemic to Java Island, and the changeable hawk-eagle is also scattered in the same island. Both types of eagles can sometimes be found in the same habitats; thus, it is interesting to see and compare the data from the satellite radio installed on these two types of raptors..

\section{Material and Methods}

\subsection{Research Site}

\subsubsection{Location of the Javan hawk-eagle release}

This research was conducted in Cagar Alam Gunung Sigogor (Nature Reserve of Mount Sigogor) which is administratively included in the Pupus Village area, Ngebel District, Ponorogo Regency, East Java Province. This area covers an area of $190.5 \mathrm{Ha}$ which is geographically located at $07^{\circ} 48^{\prime}-07^{\circ} 50^{\prime} \mathrm{S}$ and $111^{\circ} 36^{\prime}$ $111^{\circ} 38^{\prime}$ E. Cagar Alam Gunung Sigogor has a hilly topography with moderate to steep slopes and it has an altitude of 1000-1700 meters above sea level. According to Schmidt and Ferguson (1951), the climate in the region is categorized as type $\mathrm{C}$ where the average annual rainfall is $2,582 \mathrm{~mm}$ with the number of rainy days of around 142. The temperature range in this area is $15-20$ at night and 30-35 during the day [9].

* Corresponding author: gunawan215@yahoo.com 
According to Setyawati (2010) the type of vegetation in this area is mountainous tropical rain forest dominated by pasang (Quercus sondaica), jamuju (Podocarpus imbricatus), rasamala (Altingiaexcelsa), and salam (Eugenia polyantha). Several types of fauna that can be found in this area include: deer (Muntiacusmuntjak), hedgehogs (Hystrixjavanica), squirrels (Tupaia sp), garangan (Herpestesjavanicus), civets (Paradoxorushermaphroditus), rhino hornbills (Buceros rhinoceros), leopards (Panthera pardus), longtailed monkeys (Macaca fascicularis), langurs (Presbytis cristata), and various types of snakes..

\subsubsection{Location of the changeable hawk- eagle release}

The research was conducted in the Taman Hutan Raya (Tahura) Bunder (Bunder Forest Park) area, which is included in the administrative area of Gading Village, PlayenDistrict, Gunungkidul Regency, Yogyakarta Special Region (DIY Yogyakarta). This area of 617 hectares is managed under the DIY Provincial Forestry Service and is located at the coordinates of $110^{\circ} 32^{\prime} 55^{\prime \prime}$ $110^{\circ} 34^{\prime} 35^{\prime \prime}$ and $7^{\circ} 53^{\prime} 25^{\prime \prime}-7^{\circ} 55^{\prime} 10^{\prime \prime}$. With a sloping and hilly topography, this area was designated as a forest park on September 28, 2004 based on the Decree of the Minister of Forestry of the Republic of Indonesia No. 353 / Menhut -II / 2004. Tahura Bunder is dominated by plantation crops such as mahogany, teak, acacia and eucalyptus, and the animals that can be found in this area include: civets (Paradoxorushermaphroditus), deer (Muntiacusmuntjak), hedgehogs (Hystrixjavanica), squirrels (Tupaia $s p$ ), garangan (Herpestesjavanicus), and various types of birds and snakes.

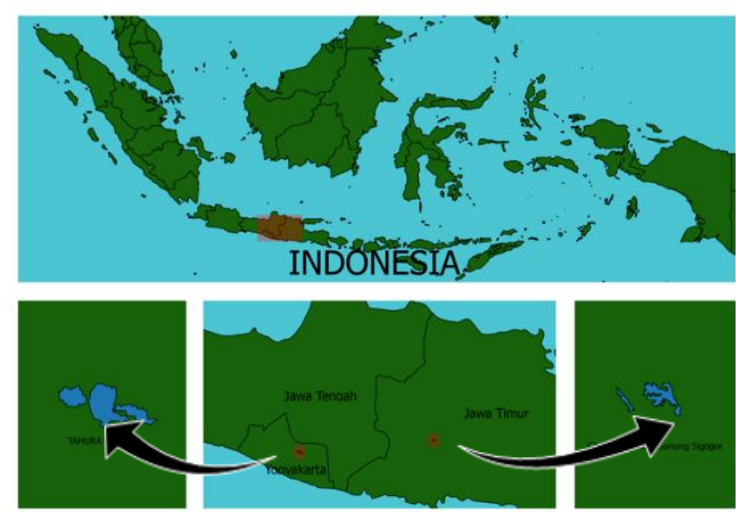

Figure 1. Map of the release locations for the Javan hawkeagle in CagarAlamGunungSigogor (East Java) andthechangeable hawk-eagle in Tahura Bunder (Yogyakarta)

\section{Metods}

The release of the two raptors followed Gunawan et al. (2017) where the release program included health checks, behavior assessments, habitat assessments, and an outreach program to the community. The release of the Javan hawk-eagle was conducted in October 2016, while the release of the changeable hawk-eagle was conducted in February 2017.

The back of the Javan hawk-eagle is fitted with a radio satellite tracker with the GPRS Solar type with the serial number 4564, while the changeable hawk-eagle is fitted with a device of the same type with serial number 4566.The collected data is accessed via www.movebank.org for further analysis using Kernel Density Estimators (KDE) through the Home Range Tools in Arc- GIS 10.4 software [2].

\section{Result and Discussion}

Based on the information collected by satellite, the acquired data were as follows :

Table 1. Comparisons of the Javan Hawk-eagle and the Changeable Hawk-eagle upon Release

\begin{tabular}{|c|c|c|c|}
\hline No & Item & $\begin{array}{c}\text { Javan } \\
\text { Hawk-eagle }\end{array}$ & $\begin{array}{l}\text { Changeable } \\
\text { Hawk-eagle }\end{array}$ \\
\hline 1 & $\begin{array}{l}\text { Duration } \\
\text { of } \\
\text { monitoring }\end{array}$ & 45 days & 40 days \\
\hline 2 & Habitat & $\begin{array}{l}\text { Mostly } \\
\text { used area of } \\
\text { forest plants } \\
(51 \%)\end{array}$ & $\begin{array}{l}\text { Mostly used } \\
\text { area of teak } \\
\text { garden and } \\
\text { secondary } \\
\text { forest }(43.9 \%)\end{array}$ \\
\hline 3 & $\begin{array}{l}\text { Habitat } \\
\text { type }\end{array}$ & $\begin{array}{l}\text { Habitat type } \\
\text { used: } \\
\text { a. secondary } \\
\text { forest dry } \\
\text { lands } \\
\text { b. plantation } \\
\text { forests }\end{array}$ & $\begin{array}{l}\text { Habitat type us } \\
\text { ed: } \\
\text { a. settlements } \\
\text { b. teak forests } \\
\text { and seconda } \\
\text { ry forests } \\
\text { c. rice } \\
\text { fields/ fields } \\
\text { d. rivers }\end{array}$ \\
\hline 4 & Movement & $\begin{array}{l}\text { Following } \\
\text { the regional } \\
\text { flow of the } \\
\text { river from } \\
\text { upstream to } \\
\text { downstream }\end{array}$ & $\begin{array}{l}\text { Following the } \\
\text { regional flow of } \\
\text { the river from } \\
\text { downstream to } \\
\text { upstream }\end{array}$ \\
\hline 5 & $\begin{array}{l}\text { The furthes } \\
\mathrm{t} \\
\text { distance }\end{array}$ & $\begin{array}{l}\text { The longest } \\
\text { flight } \\
\text { distance } \\
\text { occurred on } \\
\text { the } 24 \text { th day }\end{array}$ & $\begin{array}{l}\text { The longest flig } \\
\text { ht distance } \\
\text { occurred on the } \\
\text { 26th day }\end{array}$ \\
\hline 6 & $\begin{array}{l}\text { Total distan } \\
\text { ce } \\
\text { traveled }\end{array}$ & $40,865.48 \mathrm{~m}$ & $47,878 \mathrm{~m}$ \\
\hline 7 & $\begin{array}{l}\text { Flying } \\
\text { average }\end{array}$ & $\begin{array}{l}908.12 \\
\mathrm{~m} / \text { day }\end{array}$ & $\begin{array}{l}1,196.95 \\
\text { m/ day }\end{array}$ \\
\hline 8 & $\begin{array}{l}\text { Total roam } \\
\text { range }\end{array}$ & $101.8522 \mathrm{Ha}$ & $135,407 \mathrm{Ha}$ \\
\hline 9 & $\begin{array}{l}\text { Roaming } \\
\text { average }\end{array}$ & $\begin{array}{l}2,263.38 \\
\mathrm{Ha} / \text { day }\end{array}$ & $\begin{array}{l}3,385.18 \\
\mathrm{Ha} / \text { day }\end{array}$ \\
\hline
\end{tabular}



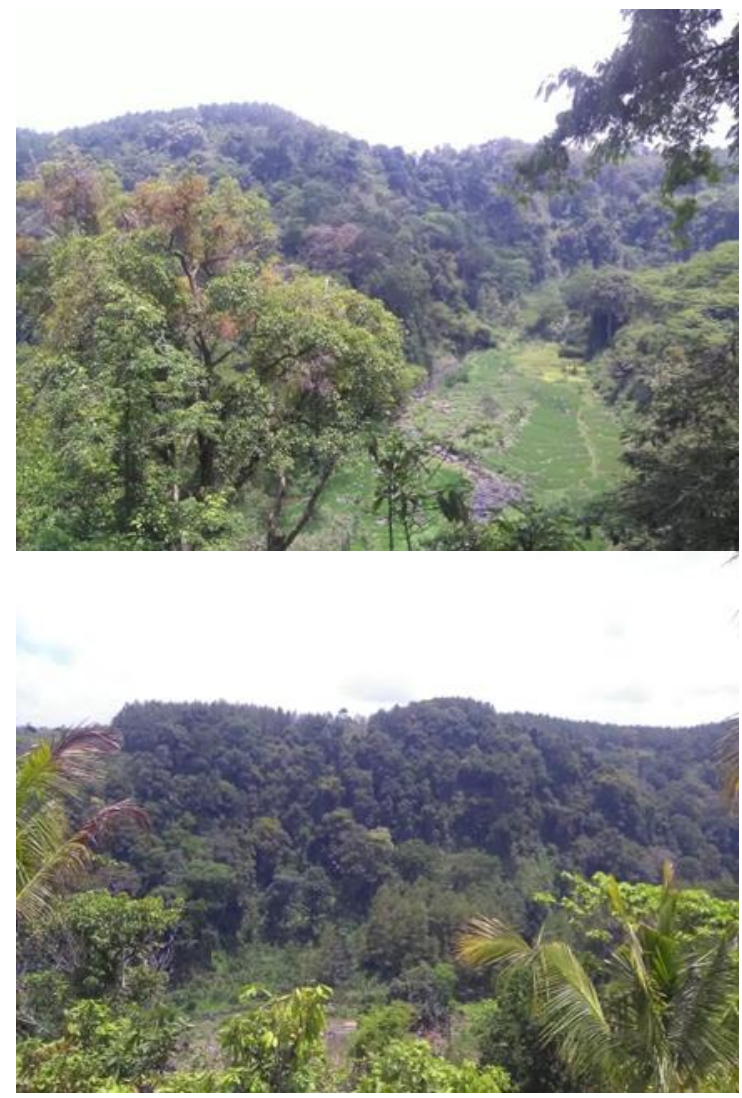

Figure 2. Chosen habitat of the released Javan hawk-eagle

From the abovementioned results it can be seen that the Javan hawk-eagle was monitored by the satellite longer than the changeable hawk-eagle. The changeable hawk-eagle was found dead in the last location with the satellite tracker still attached to its body, while the fate of the Javan hawk-eagle was not known until the time when the satellite no longer transmitted data.

From Table 1 it can be seen that both the Javan hawk-eagle and the changeable hawk-eagle mostly used large forested areas as their roaming range. The released Javan hawk-eagle used the totality of its roaming range in the form of forests which was in accordance with a study from [11], while the changeable hawk-eagle, in addition to forests areas, also used residential and fields. This is consistent with the statement of Ferguson and David. 2001 in Prawiradilaga et al., (2003) that changeable hawk-eagles, in addition to forests areas, also like meadows, forests, and areas around the riverbanks.

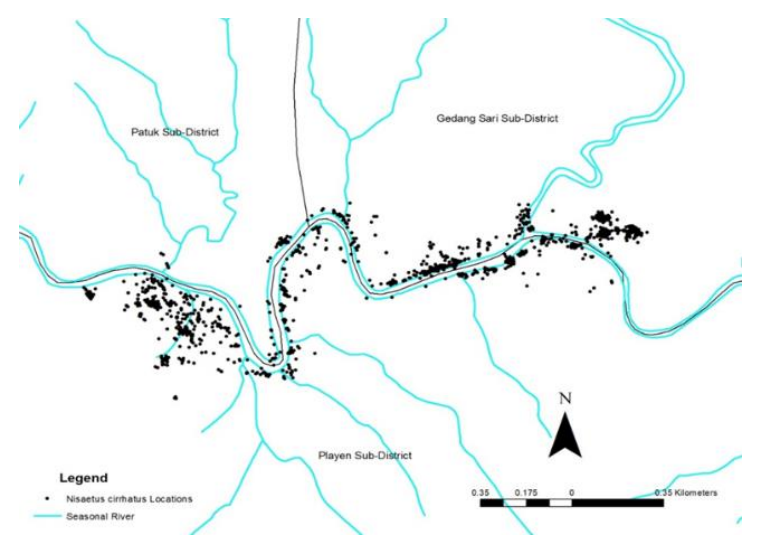

Figure 3. Activity points of the released changeable hawkeagle.

Both types of eagles moved along the river. The changeable hawk-eagle followed the upstream flow of the river while the Javan hawk-eagle followed the downstream flow of the river. The daily flight averages of the two types of eagles were almost the same, $\pm 1,000$ $\mathrm{m}$ /day, with the longest flight distance for both of them occurring in week 4. Although the selection for the release location is usually done after a strict and thorough process [4], the releasedeagle-hawks will explore new habitats in the first 2-4 weeks [7] so that the roaming range is very wide. This roaming range will gradually become more narrow andrelatively more permanent after finding a suitable habitat [4]. During the searching process, the high movement of the hawkeagles may also result from their displacement by the natural occupants in the area (Dawn et.al , 2019).

Gjershaug et al (2004) say that the average roaming range of the Javan hawk-eagle in Gunung Halimun Salak National Park and Gunung Gede Pangrango National Park is $230-710$ ha, with $41 \%$ of it in the form of forests. From the table above it can be seen that the average area of daily roaming of the Javan hawk-eagle was 3385.18 hectares, almost entirely in the form of forests (plantation forests and secondary forests). The wide roaming range of the released hawk-eagles is probably due to the exploration for new habitats.

From the data above, it can be concluded that the rehabilitation process for the Javan hawk-eagle and the changeable hawk-eagle was successful, and that they could adapt to their new habitat as wild eagles.

\section{Acknowledgment}

We would like to thanks to PT.Pertamina Fuel Madiun for the funding support, Max Plack Institute for the satellite tracker devices, and member of all about garuda team.

\section{References}

1. Fajar D.N.A., Tri Wahyu W., Gunawan, Ruli Marzuli, Sigit Trahnawan, \& Eddy Kurniawan. 2019. Program Pelepasliaran Elang Jawa di Kawasan Cagar Alam Gunung Picis dan Cagar Alam Gunung Sigogor, Jawa Timur. Jurnal Metamorfosa 6(2): 237-243

2. Fischer, J.W., Walter, W.D.\&Avery, M.L. 2013) Brownian Bridge Movement Modelsto CharacterizeBirds' HomeRanges: Modelosde Movimientode Puente Browniano Para Caracterizarel Rangode Hogarde las Aves. The Condor, 115, 298-305.

3. Gjershaug J.O., Røv N., Nygard T., Prawiradilaga D.M., Afianto M.Y., Hapsoro M.Y. \&Supriatna A. 2004. Home-range size of the Javan Hawk-Eagle (Spizaetus bartelsi) estimated from direct observations and radiotelemetry. Journal of Raptor Research. 38: 343-349 
4. Gunawan, Zulham, Pramono, H., Djamaludin, Yuniar, A., Hardina, K., Etal. (2017)

Releaseofconfiscatedraptors in Indonesia by Suaka Elang (Raptor Sanctuary): protocols and progress to date. BirdingASIA, 27, 88-93.

5. Johnston, J.1. (2007) Home Analysis of Rehabilitated and Released Great Horned Owls (Bubo virginianus) in Denton County, Texas, Trough Radio Telemetry. University of North Texas

6. Prawiradilaga D. M., Muratte T, Muzakkir A, Inoue T, Kuswandono, Adam A.S, Ekawati D, Afianto M. Y, Hapsoro, Ozawa T, dan Noriaki S. 2003. Panduan Survei Lapangan dan Pemantauan Burung-burung Pemangsa. Biodiversity Conservation Project-JICA. Japan Internacional Cooperation Agency.

7. Rahman Z., Nugroho H., Kristiawan O., Gunawan, Setyadi T., Donna K., Haryanta S., Susanto H. A. Release and monitoring progamme of the WhiteBellied Sea Eagle Haliaeetus leucogaster at Karimunjawa Island, central Java, Indonesia (Abstract). - Proceedings of the 4th Symposium on Asian Raptors 2005. Committee for the 4th Symposium on Asian Raptors 2005 / J. Abu, M.H.N. Chong, A.C. Sebastian \& Y.C. Aik (eds). Kuala Lumpur, Malaysia, 2005. P. 221.

8. Strandberg, R., Alerstam, T., Hake, M.\& Kjellén, N. (2009) Short-distance migration of the Common Buzzard Buteo buteo recorded by satellite tracking. Ibis, 151, 200-206.

9. Setyawati, T. 2010. Pemanfaatan Pohon Berkhasiat Obat di Cagar Alam Gunung Picis dan Gunung Sigogor, Kabupaten Ponorogo, Jawa Timur. Penelitian Hutan dan Konservasi Alam. Vol. VII No. $2: 177-192$

10. Schmidt, F.H. and J. H. A Ferguson. 1951. Rainfall Types Based on Wet and Dry Period Ratios for Indo-nesian with Western New Guinea. Kementrian Perhubungan Jawatan Meteorologi danGeofisika. Jakarta.

11. Thiolay, J.M. \& Meyburg, B.U. 1988. Forest fragmentation and the conservation of raptors: A survey on the island of Java. Biological Conservation, 44(4): 229-250. 